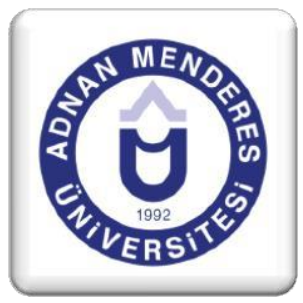

\title{
Türkiye'nin Enerji Politikalarının, Nükleer Enerji Tercihindeki Etkisi
}

\author{
Kıymet YAVUZASLAN ${ }^{1}$
}

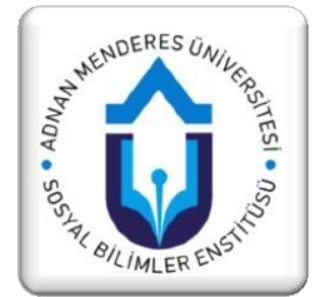

\section{ÖZET}

İstikrarlı ve sürdürülebilir bir ekononik kalkınma için ülkelerin kendi enerji politikalarını geliştirmeleri ve enerjide dışa bağımlılığı azaltmaları gerektiği tüm akademik çevrelerce kabul edilen bir gerçektir. Diğer yandan dünya düzeni içerisinde ekonomik ve sosyal bakımdan daha güçlü olmak isteyen ülkelerin, enerji kaynaklarının konumlandığı bölgelere yönelik askeri güç politikaları da enerjinin ne kadar önemli olduğunun göstergesidir. Dünyada giderek artan enerji talebinin de etkisiyle enerji alanında yaşanan gelişmeler hem ekonomik hem de toplumsal yapıyı derinden etkilemektedir. Sanayileşme ve teknolojik ilerlemeler sonucunda, Türkiye ekonomisinin enerjide dışa bağımlılığı giderek artmaktadır. Bu çalışmada görülmüştür ki; Türkiye'nin son dönemdeki enerji politikalarının ötesinde öncelikle yenilebilir enerji potansiyelini dikkate alarak diğer alternatif enerji kaynaklarını daha çok hesaplamalarına dahil ederek, bir enerji politikası oluşturması ve dünyanın ikinci en büyük toryum rezervine sahip olan bir ülke olarak yeni teknolojilerin kullanıldığı bir nükleer enerjiye geçiş sürecini tekrar değerlendirmesi gerekmektedir.

Anahtar Kelimeler: Enerji, Alternatif Enerji Kaynakları, Nükleer Enerji

Jel Kodlart: E24, J01, J21

\section{The Effect of the Turkey's Energy Policies to the Nuclear Energy Decision}

\begin{abstract}
It is a fact accepted by all academic circles that countries need to improve their energy policies and reduce energy external dependency for a stable and sustainable economic development. In addition, the military power politics of the countries which want to be stronger in economic and social care within the world order, for the regions where the energy resources are located are also indicators of how important energy is. With the effect of increasing energy demand in the world, developments in the field of energy deeply affect both economic and social structure. As a result of industrialization and technological progress, Turkey's energy import dependency is increasing. This study shows that; beyond Turkey's energy policy in the recent period primarily Turkey should take into account while generating the energy policy with the renewable energy potential as including more computing alternative energy sources and a nuclear power transition process that uses new technology as a country with the world's second largest thorium reserves re-evaluation of required.
\end{abstract}

Keywords: Energy, Alternative Energy sources, Nuclear Power, Turkey

Jel Codes: E24, J01, J21

\footnotetext{
1 Aydın Adnan Menderes Üniversitesi - Aydın İktisat Fakültesi, kiymet.yavuzaslan@adu.edu.tr
} 


\section{Giriș}

Birçok gelişmekte olan ülkede olduğu gibi Türkiye'nin de ekonomik büyüme potansiyeli enerji ihtiyacında artışa neden olmaktadır ve gelecekte de bu artışın hızlanmasının beklenmesi son derece doğaldır. Enerji konusunda uluslararası ortamda meydana gelen gelişmelerin yanında sanayileşme ve teknolojik gelişmelerin getirdiği enerji ihtiyacındaki artış, Türkiye'nin dışa bağımlılığının da giderek artmasına sebep olmuştur. Özellikle 2014 yılından sonra petrol fiyatlarının düşmesi, petrol fiyatlarındaki dalgalanmalar konusunda ülke ekonomilerinde yaşanan değişimleri de beraberinde getirmiştir. Enerji bağımlılığı yüksek, petrol ithalatçısı ülkelerin cari açıklarındaki farklar gözle görünür şekilde azalmıştır. Öte yandan petrol ve doğal gaz gibi temel enerji kaynaklarının yoğun olduğu, Orta Doğu ülkelerinde yaşanan siyasi ve sosyal istikrarsızlıklar, enerjinin temininde risk algısını yükseltmiş yeni (alternatif) enerji kaynaklarının geliştirilmesi ve enerji depolama gibi konularda hassasiyeti tüm dünyada artmıştır. Çin gibi ekonomik açıdan iddialı bir büyümeyi hedefleyen pek çok ülke enerji politikalarını belirleme aşamasında, her ne kadar nükleer enerjiye karşı olumsuz lobiler olsa da yeni nükleer santraller kurma yönünde çalışmalara da yer vermektedirler. Ülkelerin cari açık vermeden, daha rekabetçi, istikrarlı ve sürdürülebilir bir büyüme sağlamak için enerji politikalarını bu yönde geliştirmeleri gerekmektedir.

Çevreye dost yeşil enerji olarak da adlandırılan yenilebilir enerji kaynaklarının üretiminde kullanılan teknolojide, Türkiye'nin halen tam olarak yerli üretime geçememesi yenilenebilir enerji kaynağında halen yeterli ivmeyi kazanamamasına neden olmaktadır. Çok fazla gündeme gelmiyor olsa da Türkiye'nin nükleer enerji santrali kurma girişimleri devam etmektedir. Mersin'de kurulacak ilk nükleer santral için Rusya ile 2010 y1lında ve Sinop'ta kurulacak nükleer santral için 2013 yılında Japonya ile anlaşmalar sağlanmıştır. Öte yandan Türkiye'nin nükleer enerji konusundaki adımlarını atarken artık sadece kamu tarafında tartışma platformları oluşturmaması gerekmektedir.

Türkiye'nin nükleer enerjiye ihtiyacı olup olmadığına karar verirken, gerek dünya çapında faaliyet gösteren kuruluşların analizlerini gerek akademik çevreyi gerekse sivil toplum kuruluşlarını da karar sürecine dahil etmesinde fayda bulunmaktadır. Böylece nükleer konusunda acele etmeyerek kendisinden doğalgaz ithal ederek halihazırda enerji konusunda bağımlı olduğumuz Rusya ve yakın zamanda Fukushima gibi büyük bir nükleer santral faciası yaşamış Japonya ile anlaşma imzalamak yerine Türkiye, daha farklı bir yol izleyebilir miydi? Elektrik üretimini daha temiz, daha güvenilir ve toryum zenginliği bakımından dünyada ikinci olmanın sağladığı kaynak zenginliği ile muhtemelen daha ucuz bir şekilde elektrik üretimi yapabilecekken, nükleer santral kurulumu konusunda aceleci bir hamle yapmış ve güncel teknolojik gelişmeler 1şığında yeni teknoloji nükleer santral kurulumunu sağlama firsatını da kaçırmıştır. "Türkiye'nin ekonomik büyümesi, cari açığını azaltmak ve refah düzeyine ulaşabilmek v.b. birçok gerekçe ile nükleer enerji Türkiye için şarttır" şeklindeki ifadeler yerine nükleer santralin tüm eksilerini ve artılarını tartışması ve Türkiye'nin diğer potansiyellerini de devreye sokarak gelecekteki enerji ihtiyacı için sağlıklı bir projeksiyon hazırlaması gerekmektedir. Bu çalışmada; nükleer enerji gerçeğinin detaylı bir analizi yapılarak avantaj ve dezavantajları ortaya konmaya çalışılacak, enerji-cari açık çıkmazı da dikkate alınarak Türkiye'nin mevcut enerji kaynakları potansiyeli ile enerji açığını telafi etmesinin mümkün olup olmadığı ve nükleer enerjinin Türkiye için gerekliliği analiz edilmiştir. 


\section{Türkiye'nin Enerjide Dışa Bağımlılığı}

En temel mal ve hizmet üretiminin arttırılması sırasında bile daha fazla enerjiye ihtiyaç duyulmaktadır. Enerji talebi artışı ile GSMH artışı arasında sıkı bir ilişki vardır. Eğer yeterli enerji artışı yoksa mal ve hizmet üretimi de arttırılamaz. Dolayısıyla GSMH artışı veya büyüme oranı doğrudan doğruya enerji artışına ya da enerjideki büyüme oranına bağlıdır (Hamilton, 1988,1996, 2000; Davis ve Haltiwanger, 2001) Günümüzde kalkınmanın ve refahın eriştiği derecenin ölçütlerinin en önemlilerinin biri de toplumların kişi başına ürettiği ve tükettiği enerji miktarıdır. Enerji ve tercih edilen enerji kaynağ 1 değerlendirilirken kaynă̆ın fiyatı, göz önüne alınmak zorundadır (Satman, 2006, s. 48). Hemen hemen her ülke için enerji, artık "kendi kendine yeterli" tanımının dışındadır. Enerji üzerinden uluslararası ticaret gündemdedir. Ticaretin temelinde ise arz ve talep vardır. Talep olması için ekonomik gelişme ve enerjiyi satın alacak insan gerekmektedir. 1950'den bu yana dünya nüfusu iki kattan fazla artarken enerji talebi ise altı kat artmıştır. Birleşmiş Milletler'in tahminine göre 2017 yılında dünya nüfusu yaklaşık 7,6 milyardır. Bu sayının, 2050 yılında 8,9 milyar olması tahmin edilmektedir. Nüfus arttıkça enerji kullanımı da artan oranda artacağından, ilerleyen yıllarda tüm dünyada kişi başına enerji tüketiminin artması beklenmektedir (WEC, 2013:48).

Tablo 1: Türkiye ve Diğer Ülkelerde Elektrik Fiyatları (ABD cents/kwh)

\begin{tabular}{|l|l|l|}
\hline Ülke & Sanayi & Konut \\
\hline Türkiye & 14 & 17 \\
\hline Brezilya & 12,2 & 16,6 \\
\hline Meksika & 11,1 & 9,5 \\
\hline Hindistan & 10,5 & 6,1 \\
\hline Çin & 9,6 & 6,7 \\
\hline Kore & 7 & 10 \\
\hline
\end{tabular}

Kaynak: Süreyya Yücel Özden, "Türkiye Ekonomisi Enerji Diplomasisi”, Dünya Enerji Konseyi Türk Milli Komitesi, İstanbul, 20 Kasım 2008.

Sosyal refah göstergesi olan ve diğer sektörlerde temel girdi olarak kullanılan enerji, sanayini ve ekonomik kalkınmasını süratle geliştirmek isteyen Türkiye'de, gerekli teknolojik imkanlarla, istikrarlı bir şekilde arz edilmelidir. Aksi takdirde, enerji üretiminde dışa bağımlı kalınarak sanayi atılımlarının sürdürülmesi her zaman mümkün olmayabilir (Başol, 1994, s. 161). Türkiye enerji kaynakları rezervi bakımından zengin bir ülke değildir şeklindeki genel kanının ötesinde, cari açık içerisinde enerji ithalatının payı nedeniyle Türkiye'nin enerjide dışa bağımlılı̆̆ yüksektir (Tecer, 2003: 31).

Türkiye'nin enerji ithalatı ve cari açık ilişkisi konusunda, ekonomi yazınında pek çok çalışma bulunmaktadır (Demir, 2013; Kaya ve Kursunoğlu, 2014; Uysal vd., 2015). Bu çalışmalar da Türkiye'nin cari açığında enerji ithalatından kaynaklandığını göstermektedir. Öte yandan Türkiye'nin elektrik enerjisi üretiminde yoğun bir şekilde kullandığı petrol fiyatlarındaki talep düşmesi sebebiyle ve maliyetlerin artmasıyla beraber ekonomideki daralma işsizliği arttırmakta ve yılda 800.000 kişinin işsiz kalmasına neden olmaktadır. Petrol fiyatlarındaki 20 dolarlık artış dünya genelinde gayri safi yurt içi hasılalarda yüzde 
1'lik artışa neden olmaktadır (Arı, 2007: 49). Aynı şekilde, kurlarda yaşanan dalgalanmalar da doğrudan doğal gaz fiyatlarını etkilemektedir.

Rakamlar açısından Türkiye'nin cari açık verileri incelendiğinde de örneğin 2012 yılında 48,9 milyar dolar olan cari açığının, 60,1 milyar dolarlık enerji ithalatı çıkarıldığında 12 milyar dolarlık cari fazlamız olabileceği gerçeği ile karşılaşılır.

Türkiye'nin daha önce 60-70 milyar dolar civarlarında olan enerji ithalat1, 2015 yılında 37,8 milyar dolara kadar düşmüştür. EPDK tarafından yapılan açıklamalarda enerji ithalatında sağlanan verimin en büyük nedenlerinden birisinin de 2013-2015 yılları arasında uygulanan enerji politikalarının olduğu vurgulanmaktadır. Türkiye'nin elde etmiş olduğu bu başarı, 2012 yılına kadar izlediği enerji politikalarının dışına çıkarak daha sağlam adımlar attığını da göstermektedir.

\section{Türkiye'nin Enerji Politikaları}

Türkiye'de enerji üretim ve tüketiminin gelişimi incelendiğinde son kırk yılda ekonomik ve teknolojik gelişmeler ile beraber arttığı görülmüş̧ür. Enerji sektöründe üretimin büyük bir kısmını kamu kesimi üstlenirken özellikle planlı dönemde kamunun enerji sektörüne yaptığ yatırımlar çok önemli pay almıştır. Üretimin talebi karşılamadığ 1 enerji kaynakları, ithalat ile karşılanmaya çalış1larak tüketime sunulmuştur (Karluk, 2014: 261). Türkiye, enerji gereksiniminin büyük çoğunluğunu ağırlıklı olarak fosil yakıtlardan sağlamakta, elektrik enerjisi üretiminin yüzde 26'sı hidrolik, yüzde 74'ü ise fosil kaynaklardan gerçekleşmektedir (Dündar- Arıkan, 2003: 176).

Türkiye'de birincil enerji kaynakları arasında önemli bir yeri olan taşkömürünün bilinen rezervi 1 milyar 126 milyon, petrol rezervi ise 46,3 milyon tondur. Birincil enerji tüketiminde önemli pay, petrol ve petrol ürünlerine aittir. İkinci sırada linyit, üçüncü sırada doğal gaz gelmektedir. Taşkömürü ve linyit kullanım oranlarında son yıllarda istikrar gözlenirken petrol ve petrol ürünlerinde düşüş, buna karşl1ık doğal gaz tüketiminde gözle görülür bir artış görülmektedir (Karluk, 2014: 260).

Türkiye'nin elektrik ihtiyacının büyük bir kısmını karşılayan hidrolik kaynakları Avrupa'nın toplam hidrolik kaynaklarının yüzde 16'sını oluşturmaktadır (TÜYAP, 1998: 3). Ancak küresel isınmayla beraber su kaynaklarında meydana gelen azalma hidroelektrik santrallerin tam kapasite ile çalışmasına imkan vermemektedir.

Türkiye'nin ulusal enerji arzının talebi karş1layamaması ve ekonomik kriz dönemleri her yıl ortalama yüzde 8'lik bir enerji talep artışıla karşı karşıya kalması enerji politikasının çerçevesini belirleyen bir etmendir (Güney, 2003: 11). 
Tablo 2: Dünya'da, Türkiye'nin Enerji Açısından Konumu

\begin{tabular}{|c|c|c|c|c|c|}
\hline $\begin{array}{c}\text { SIRALAMADA } \\
\text { DİKKATE } \\
\text { ALINAN } \\
\text { GÖSTERGE } \\
\end{array}$ & $\begin{array}{c}\text { TÜRKIYYE'NIN } \\
\text { SIRASI }\end{array}$ & $\begin{array}{c}\text { BİRİNCİ } \\
\text { ÜLKE }\end{array}$ & $\begin{array}{c}\text { NÜKLEER } \\
\text { SANTRAL } \\
\text { ADEDİ } \\
\end{array}$ & \begin{tabular}{|c|} 
DÜNYA \\
TOPLAMINDAKİ \\
PAYI $(\%)(2010)$ \\
\end{tabular} & \begin{tabular}{|c|} 
BİRINCI \\
ÜLKENIN \\
DÜNYA \\
TOPLAMINDAKİ \\
PAYI $(\%)(2010)$ \\
\end{tabular} \\
\hline $\begin{array}{l}\text { Dünya Birincil } \\
\text { Enerji Tüketimi }\end{array}$ & 21 & Çin & 17 & $0,9 \%$ & $20,3 \%$ \\
\hline Elektrik Üretimi & 20 & $\mathrm{ABD}$ & 100 & $1,0 \%$ & $20,3 \%$ \\
\hline $\begin{array}{l}\text { Doğalgaz } \\
\text { Tüketimi }\end{array}$ & 24 & $\mathrm{ABD}$ & 100 & $1,2 \%$ & $21,7 \%$ \\
\hline $\begin{array}{l}\text { Doğalgaz } \\
\text { İthalatı }\end{array}$ & 8 & $\mathrm{ABD}$ & 100 & & \\
\hline $\begin{array}{l}\text { Ülkelerin } \\
\text { Rusya'dan } \\
\text { Doğalgaz } \\
\text { İthalatı }\end{array}$ & 4 & Almanya & 9 & & \\
\hline $\begin{array}{l}\text { Hidroelektrik } \\
\text { Enerji Tüketimi }\end{array}$ & 12 & Çin & 17 & & \\
\hline Kömür Üretimi & 11 & Çin & 17 & $0,5 \%$ & $48,3 \%$ \\
\hline Kömür Tüketimi & 15 & Çin & 17 & $1,0 \%$ & $48,2 \%$ \\
\hline $\begin{array}{l}\text { Dünya Jeotermal } \\
\text { Enerji Kapasitesi }\end{array}$ & 14 & $\mathrm{ABD}$ & 100 & $0,7 \%$ & $28,4 \%$ \\
\hline $\begin{array}{l}\text { Dünya Güneş } \\
\text { Enerjisi } \\
\text { Kapasitesi } \\
\end{array}$ & 29 & Almanya & 9 & & $43,5 \%$ \\
\hline $\begin{array}{l}\text { Dünya Rüzgar } \\
\text { Enerjisi } \\
\text { Kapasitesi } \\
\end{array}$ & 16 & Çin & 17 & $0,8 \%$ & $22,4 \%$ \\
\hline
\end{tabular}

Kaynak: IAEA ve ETKB'den uyarlanmıştır.

Tablo 2'de görüleceği üzere Türkiye, pek çok ülkeden daha fazla doğalgaz ithalatı yapmaktadır. Tablo incelendiğinde yeraltında bulunan birincil enerji kaynakları bakımından Türkiye'nin zengin bir ülke olmadığ 1 görülmektedir. Öte yandan petrol rezervleri ile ilgili rakamların gerçekleri yansıtmadığ ${ }_{1}$ idea edilmektedir. Çünkü Türkiye'nin yeraltı jeolojisi çok az bilinmektedir ve birçok yöresinde kara ve denizlerinde teknik, ekonomik ve politik nedenlerle yer altı rezervleri için aramalar yapılamamıştır (Gürel, 1980: 115). Diğer taraftan Türkiye'nin enerji rezervleri açısından büyük bir potansiyele sahip taşkömürü ve linyit konusundaki en önemli sorun, ortaya çıkan enerji bakımından kalitesiz oluşlarıdır. $\mathrm{Bu}$ durum, kömüre dayalı enerji üretiminin belli seviyelerin üzerine çıkmasını hem çevresel etkiler, hem de maliyet yüksekliği sebebiyle imkansız kılmaktadır. Türkiye'de 8 milyar 74 milyon ton olarak tahmin edilen linyit rezervlerinin büyük bir kısmı elektrik üretimi için gerekli enerjiyi sağlayamadığından ve çevreye olumsuz etkilerinden dolayı Türkiye'de kömür rezervleri genelde elektrik üretiminde değil ısınma amaçlı kullanılmaktadır (TÜYAP, 1998: 12).

Türkiye'nin enerji politikalarında yeni enerji alternatiflerindeki durumunu değerlendirmek üzere bu bölümde Türkiye'nin yenilenebilir ve nükleer enerji politikaları incelenecektir. 


\subsection{Türkiye'de Yenilenebilir Enerji}

Türkiye enerji rezervlerinin sınırlı olduğu yenilenebilir enerji kaynakları açısından oldukça zengin bir potansiyeli olmasına rağmen, alternatif enerji kaynakları iyi değerlendirilemediği düşünülmektedir.

2016 y1lsonu itibarıyla Türkiye'nin yenilenebilir enerji toplam kurulu gücü yaklaş1k 35 GW olarak hesaplanırken, bu kurulu gücün büyük çoğunluğunu hidrolik enerji oluşturmaktadır. Rüzgar ve güneş gibi modern yenilenebilir enerji çeşitleri olarak tanımlanan kaynakların oranları yıllar içerisinde artmasına ve Türkiye'nin enerji ihtiyacının yüzde 86'1sını karşılayabilecek yenilenebilir enerji potansiyeli olmasına rağmen toplam elektrik üretiminin ise yüzde 35'i yenilenebilir kaynaklar tarafından karşılanmaktadır (Karagöl ve Kavas, 2017: s. 87).

Tablo 3: Türkiye'nin Yenilenebilir Enerji Kaynakları Potansiyeli ve Kaynakların Tamamı Kullanıldığında Elde Edilebilecek Üretim Projeksiyonu

\begin{tabular}{|c|c|c|c|c|c|c|}
\hline $\begin{array}{c}\text { Türkiye'nin } \\
\text { Yenilebilir } \\
\text { Enerji } \\
\text { Kaynakları } \\
\end{array}$ & $\begin{array}{c}\text { Toplam } \\
\text { Kurulu Güç } \\
\text { Potansiyeli } \\
\text { (MW) } \\
\end{array}$ & $\begin{array}{c}\text { Mevcut } \\
\text { Kurulu } \\
\text { Güç (MW) } \\
\end{array}$ & $\begin{array}{l}2011 \text { Yılı } \\
\text { Elektrik } \\
\text { Üretimi } \\
\text { (GWh) } \\
\end{array}$ & $\begin{array}{c}2023 \\
\text { Hedefi } \\
\end{array}$ & $\begin{array}{c}2023 \text { Hedefi } \\
\text { Kapsamında } \\
\text { Yıllık Ortalama } \\
\text { Üretim } \\
\text { Potansiyeli } \\
\text { (Milyon } \\
\text { kWh/yıl) } \\
\end{array}$ & $\begin{array}{c}\text { Güç } \\
\text { Potansiyelinin } \\
\text { Tamamı } \\
\text { Kullanıldığında } \\
\text { Elde } \\
\text { Edilebilecek } \\
\text { Üretim (Milyon } \\
\text { kWh/yıl) } \\
\end{array}$ \\
\hline Hidro & 36.000 & 16.934 & 52.067 & 36.000 & 144.000 & 144.000 \\
\hline Rüzgar & $48.000 *$ & 1.587 & 4.726 & 20.000 & 60.000 & 144.000 \\
\hline Güneş & $50.000 * *$ & - & - & 3.000 & 7.500 & 125.000 \\
\hline Jeotermal & 600 & 94 & 699 & 600 & 4.400 & 4.400 \\
\hline Biyokütle & 2.000 & 44 & 525 & 2.000 & 14.000 & 14.000 \\
\hline Toplam & 136.600 & 18.659 & 58.017 & 61.600 & 229.900 & 431.400 \\
\hline
\end{tabular}

Kaynak: ETKB'den uyarlanmıştır

* Yer seviyesinden 50 metre yükseklikte yıllık ortalama 7 metre/sn. hız ile çalışan rüzgar santralleri kullanıldığında 48.000 MW'lık doğalgaz santralinin üreteceği elektrik miktarı kadar elektrik üretilebilir.

** Enerji odaklayıcı güneş sistemi kullanıldığında 50.000 MW'lık doğalgaz santralinin üreteceği elektrik miktarı kadar elektrik üretilebilir.

ETKB tarafından Türkiye'nin nükleer enerjiye olan ihtiyacını ortaya koymak amacıyla yayınlanan "Nükleer Santraller ve Ülkemizde Kurulacak Nükleer Santrallere İlişkin Bilgiler" adlı yayınından uyarlanarak hazırlanana Tablo 3, Türkiye'nin yenilebilir enerji potansiyelinin tamamı kullanılarak elde edilebilecek toplam elektrik enerjisi hesaplanmıştır.

Melikoğlu (2013) "Hedef 2023:Türkiye'nin Enerji Projeksiyonun Fizibilite Analizi” adlı çalışmasıyla yenilenebilir enerjinin Türkiye'ye olası maliyetinin hesaplandığı çalışmasında; 2023 yılına kadar Türkiye'nin 530.000 GWh civarında olması beklenen enerji ihtiyacının tamamının yenilenebilir enerjiyle ya da sadece kömür ve doğal gazdan karşılanması dikkate 
alınarak iki ayrı senaryo oluşturmuştur. Türkiye'nin yenilenebilir enerji kaynakları ile üretimi sağlayan kurulu gücü şuan $60.000 \mathrm{GWh}$ civarındadır ancak Melikoğlu'nun da belirttiği gibi ayrıntılı bir literatür taraması ve ETKB'nin yayınladığı rakamlara bakıldığında sadece güneş ve rüzgar enerjisi potansiyelinin tam kapasiteyle değerlendiren bir Türkiye, 2023 yılında gerekecek olan enerji ihtiyacının tamamını karşılayabilir. Burada sorulması gerek peki ama neden Türkiye bu potansiyeli değerlendiremiyor? Bu sorunun cevabı olarak Melikoğlu her iki senaryoda elde ettiği sonuçları karşılaştırmıştır. İlk senaryoda (Senaryo 1) yani güneş ve rüzgar enerjisi ile üretim yapıldığı takdirde Türkiye'nin tahmini harcaması 31 milyar iken Senaryo 2 kapsamında sadece kömür ve doğalgaz ile yapılan enerji üretimindeki maliyet 8 milyar dolar civarında olacaktır (Melikoğlu, 2013, 570-575).

Öte yandan Uluslararası Yenilenebilir Enerji Ajansı (International Renewable Energy Agency-IRENA)'nın Türkiye'yi de dahil ederek hazırladığı "Yenilenebilir Enerji Yol Haritası" adlı raporda yenilenebilir enerji üretiminin, devletin yapmış olduğu vergi düzenlemeleri ve sübvansiyonlardan arındırılmış maliyeti yılda 100 milyar dolar civarındadır. İşletmecilik bazında getireceği yıllık tasarruf ise yılda 30 milyar dolar. Ancak sadece bu tasarrufu dikkate almak son derece yanlıştır. Kuruluşun, çevre ve insan sağlığına zarar vermeyen özelliği yanında yenilenebilir enerji üretiminde yapılacak yatırımların enerji sektörüne sağlayacağ 1 istihdamı da veri olarak alan maliyet/tasarruf analizine göre yenilenebilir enerjiyle sağlanacak tasarruf, maliyetinden çok daha fazla olacaktır (IRENA, 2014: 25).

Türkiye enerji politikasını 2023 yılını dikkate alarak planlarken, dünya enerjinin geleceğini 2035 yılına endeksleyerek 3 ayrı senaryo ile projeksiyon oluşturmuştur. Uluslararası enerji ajansının (IEA) 2035 yılı Dünyanın Enerji görünümü için oluşturduğu bu üç farklı senaryoya göre; enerji kaynaklarının toplam enerji talebi içerisindeki paylarını çıkartmıştır şu şekilde çıkartılmıştır. 2035 yılında temiz bir enerji tüketimine ulaşabilmek için Kyoto protokolü ile de ulaşılmaya çalışılan karbondioksit salınımı hedefi olan 450 partikül sera gazı hedefine göre, mevcut politikalarla 2035 yüzde 30'a düşürülmesi planlanan kömür tüketiminin yüzde 16'ya indirilmesi gerektiği, kömür tüketimi ile yapılan tüketimin nükleer ve biyokütle/çöp gazı enerjisi ile karşılanabileceği öngörülmüştür. Mevcut politikalarla yüzde 6 olarak öngördüğü nükleer enerji ile elektrik üretimini, yeni politikalarla yüzde 7 olarak planlanmış son olarak sera gazı salınımını azaltacak olan son senaryoya göre de nükleer enerji ile üretiminin yüzde 11 olarak olması gerektiği savunulmuştur. 
Tablo 4: Dünyada ve Türkiye'de Elektrik Enerjisi Üretiminde Kullanılan Enerji Kaynaklarının Payı ve 2023 Enerji Projeksiyonu

\begin{tabular}{|c|c|c|c|}
\hline Enerji Kaynakları & Dünya & Türkiye & $\begin{array}{c}\text { Türkiye'de Nükleer } \\
\text { Santral Sonrası } \\
\text { Olabilecek Paylar }\end{array}$ \\
\hline Petrol & $5,5 \%$ & $1,0 \%$ & \\
\hline Doğalgaz & $21,3 \%$ & $46,2 \%$ & $30,0 \%$ \\
\hline Kömür & $41,0 \%$ & $25,9 \%$ & $30,0 \%$ \\
\hline Hidroelektrik Santraller & $15,9 \%$ & $24,4 \%$ & $\begin{array}{l}\text { Toplam Yenilebilir } \\
\text { Enerji Payı Olarak } \\
\text { \%30 Planlanmakta }\end{array}$ \\
\hline Nükleer Santrallerden & $13,5 \%$ & $0,0 \%$ & $10,0 \%$ \\
\hline $\begin{array}{l}\text { Diğer (Rüzgar, Güneş } \\
\text { enerjisi Çöp ve } \\
\text { Biyoenerji vb.) }\end{array}$ & $2,8 \%$ & $1,9 \%$ & $\begin{array}{l}\text { Toplam Yenilebilir } \\
\text { Enerji Payı Olarak } \\
\text { \%30 Planlanmakta } \\
\end{array}$ \\
\hline TOPLAM & 20.181 Milyar kWH & 212 Milyar kWh & 500 milyar kWh \\
\hline
\end{tabular}

Kaynak: IAEA ve ETKB'den uyarlanmıştır.

IRENA'nın yenilebilir enerjinin maliyeti konusunda yaptığı analizin yanında raporda ele alınan 26 ülkenin, 2030 yılına kadar elektrik üretiminde yenilebilir enerjinin payının yüzde 18'den yüzde 21'e çıkması öngörülmektedir (IRENA, 2014: 13-15).

\subsection{Türkiye'de Nükleer Enerji}

Nükleer enerjinin tarihi gelişimine bakıldığında; bu gücü İkinci Dünya Savaşı sırasında sadece atom bombası yapımı için kullanmayı tercih eden ABD'nin, 1950'li y1llarda Rusya'nın nükleer enerji kullanımına başlaması ile zamanla elektrik enerjisi üretimi tercihleri arasında yer almaya başlamış olduğu söylenebilir. Avrupa Birliği'nde (AB) ise nükleer enerji konusunda, birliğin kuruluş anlaşmasında herhangi bir açılım yapmasa da sonraları nükleer enerji ile ilgili düzenlemeler önem kazanmıştır.

Nükleer enerji üretiminin gündeme geldiği ilk yıllarda nükleer enerji santralleri sadece kurulum masraflarının, başka santrallere nazaran daha az olduğu yerlerde kurulduğu halde, günümüzde özellikle birincil enerji kaynaklarının tükenmesi sorunu yeni enerji kaynaklarının gelişmesi sorunu da gündeme getirdiğinden masrafların daha özenle daha dikkatli hesaplanması gerektiğini ortaya çıkarmıştır (Brown, 1964: 116).

Nükleer santralleri inşa eden müteahhit firmalar, bunları ihale eden devlet bürokrasisi ve nükleer teknolojiyi ilerlemenin kaçınılmaz bir boyutu olarak değerlendiren teknoloji çevreleriyle, nükleer santralleri istemeyen kurumlar ve vatandaş grupları arasındaki temel tartışma başlıklarından bir tanesi "nükleer santrallerin ekonomik olup olmadığı" sorusudur. Hesaplamaların bilinen ve bilinemeyen etkilerin maliyetleriyle, beklenen risk faktörleriyle, 
farklı kesimlerin değerleri ve risk algılarıyla, dışsal çevresel ortama dair farklı senaryolarla karmaşıklaşması, halkın makul sonuçlara varmasını güçleştirmektedir (Saysel, 2013).

Nükleer enerji ekonomisinin temel özellikleri şunlardır (NEA, 1998);

- Uzun planlama süresi

- Yüksek ilk yatırım maliyeti

- İssletme ömrü

- Nükleer enerji üretiminin ardından ortaya çıkan ortaya çıkan maliyetler (özellikle atıkların yönetimi ve tasfiyesi ile sökme işlemleri

Dünya'da işletilmekte olan nükleer enerji santrallerinin ilk yatırım maliyeti, diğer enerji üretim teknolojilerine göre daha yüksektir. Bu yüksek maliyetin en büyük sebebi güvenlik ve kalite anlayışındaki sonsuz maliyet önemli bir rol oynamaktadır. İlk yatırım maliyeti ülkeden ülkeye ve seçilen teknolojiye göre değişmekle beraber ortalama ilk yatırım maliyeti 20002500 \$/kW'dir (Karluk, 2014: 246).

Nükleer enerjinin, düşük üretim maliyeti, yüksek ilk yatırım maliyeti, yakıt fiyatlarındaki değişimlere karşı duyarsızlık, uzun işletme ömrü ve kayda değer yasal düzenleme maliyeti gibi birçok özelliği bulunmaktadır (Kessides, 2010:3855). Nükleer enerjinin maliyeti kilowatt saat başına 3,63 cent olarak hesaplanmıştır ancak bu fiyatın içine ilk yatırım maliyeti de eklendiğinde nükleer enerji üretim maliyeti 11,1 ile 14,5 cent $/ \mathrm{kWsaat}$ arasında bir tutara tekabül etmektedir. Reaktör kurulduktan sonra, ekonomik bakımdan yararlı hale gelebilmesi için, 10-15 yılın geçmesi gerekir. Nükleer enerji santrali kurulabilmesi için, herhangi bir termik enerji istasyonuna kıyasla iki kat paraya ihtiyaç olduğundan, alınacak borç ve borcun faizi de iki kat yüksektir. Ayrıca nükleer enerji tesislerinin sigortası da diğer elektrik üreten santrallere göre ölçülemeyecek derecede riskli görülmektedir ki birçok sigorta şirketi böyle bir riski göze almayabilir, fakat nükleer enerji kullanıldıkça sigorta bedeli azalabilir. Mevcut reaktörlerin yakıt masrafı ise göze çarpacak derecededir, fakat satın alınan miktara göre fiyat değiştiğinden, tam olarak yakıt masrafını tahmin etmek oldukça zordur. Halen 1 ton yakıtın verdiği enerji binlerce ton kömürden elde edilen enerjiye eşittir. Yılda bin ton uranyum kullanan bir reaktörde, uranyumun bir kilosu 10 sterline mal olmaktadır (Brown, 1964: 119). Sadece dişsal maliyetler (yani bir ekonomik aktivitenin başkaları üzerinde yarattığı maliyetler) söz konusu olduğunda ki burada dışsal maliyet, -radyolojik etkiler ve kaza riskidir- nükleer ile yalnızca hidroelektrik ve rüzgar enerjisi yarışabilmektedir. Yakıt maliyeti düşüktür ve nükleer santrallerin verimliliği arttıkça bu maliyet azalmaktadır; oysa fosil yakıtların maliyeti sürekli artmaktadır. Tasfiye masrafları gelecekten bugüne iskonto edildiğinde (gelecek maliyetler belirli bir iskonto oranıyla çarpıllp indirime tabi tutulduğunda) kurulum maliyetinin çok küçük bir yüzdesine tekabül etmektedir. Ancak yeni bir reaktör kurarken araştırma ve geliştirme pahalıya mal olmaktadır. Diğer enerji santralleri ile mukayese edildiğinde, nükleer enerji santrallerinin sermayede değilse de, işletme masraflarında gün geçtikçe bazı avantajlar sağlaması beklenmektedir (Kessides, 2010: 3857). Bu noktada, nükleer enerjinin ekonomisi ve enerji planlaması önemli bir konudur. Bugüne kadar yapılan analizler ekonomik ortamı yeterince uygun görmemekte ve bu enerjinin geleceğini çok büyük ölçüde kamusal desteğe bağlamaktadır. 
Özet olarak; nükleer enerji santrallerini kurmanın faydalı olup olmayacağına karar verebilmek için, iki noktanın göz önünde tutulması gerekir uzun vadede doğal kaynakların yeterliliği ve kısa vadede ise nükleer enerji üretiminin getirdiği masraflar; ki buna sermaye ile cari masraflar da dahildir (Kessides, 2010: 3858). Bu açıdan öncelikle Türkiye'nin mevcut enerji kaynakları potansiyelini irdelemekte fayda bulunmaktadır.

\subsubsection{Türkiye'nin Uranyum ve Toryum Rezervi}

Türkiye yerli kaynakları içinde yaklaşık 10.500 ton olan düşük kalitede uranyum bulunmaktadır. Salihli-Köprübaşı, Yozgat-Sorgun, Uşak-Fakılı, Aydın-Demirtepe ve Küçükçavdar sahalarında ekonomik olarak çıkarılabilecek uranyum rezervi saptanmıştır. Ayrıca bugüne kadar bulunan rezervlerin Türkiye'nin gerçek uranyum rezervlerini yansıtmadığı görüşünün de gündemde olduğu son dönemde özellikle Güney Marmara ve Doğu Karadeniz bölgelerinde yapılacak yeni aramalarla ek uranyum yatakları bulunması olasılığının fazla olduğu ve toryum rezervine bakarak Türkiye uranyum rezervinin 120 bin ton olduğu iddia edilmektedir (Külebi, 2007: 179).

Uranyum aramalarına Türkiye'de 1990 yılı sonuna kadar devam edilmiş ve 5 yatakta toplam 9.129 ton görünür uranyum rezervi ortaya konulmuştur. 1990 yılından sonra zaman zaman yapılan aramalar kısıtlı bütçe ile sınırlı alanlarda yapılmıştır. Bu uranyum yataklarının ortalama tenör ve rezervleri, aranıp bulundukları yıllarda, dünyaca kabul edilen ekonomik sınırlarda olmalarına rağmen, bugün için, bu değerler söz konusu sınırların oldukça altında kalmıştır. Bunun nedeni, son yıllarda nükleer santral planlamalarındaki önemli değişmelerdir (DPT, 2006: 1) ki - dünyada kabul edilebilir masraflarla çıkarılabilecek, bilinen uranyum rezervleri, şu anki kullanım şartları altında en çok 60 ila 80 yılda tükeneceği tahmin edilmektedir (Bonanni, 2017) - ve ekonomik açıdan kullanılabilirliği şu an için sorgulansa bile toryum ve uranyum açısından Türkiye'nin yerli kaynaklarının varlığı gelecekte nükleer enerji kullanımında Türkiye için güvencedir (Külebi, 2007: 179). Ö̈zellikle toryum rezervlerine sahip önemli ülkeler Arjantin, Avustralya, Brezilya, Kanada, Mısır, Norveç, Tayland ve Türkiye'dir. Türkiye 380.000 ton toryum rezervi ile dünyanın en zengin toryum rezervine sahip ülkesidir. Bu rezerv dünya toplam toryum rezervinin yüzde 41'ine eşittir (DPT, 2006:1). Nükleer enerjide yakıt maliyetinin toplam üretim maliyeti içindeki yerinin yaklaşı yüzde 10-12 olması ve dünyadaki uranyum stoklarının ve rezervlerinin fazlalığ nedeniyle gelecekte yakıt maliyetinin fazla bir değişim ve artışın beklenmemesi de, ithal uranyum ile bile nükleer enerjiye geçiş için özendirici özelliklerdir (Külebi, 2007: 179). 
Tablo 5: Dünya Toryum Rezervi ve Türkiye'nin Yeri

\begin{tabular}{|l|c|c|}
\hline \multicolumn{1}{|c|}{ Ülke } & Toryum Rezervi (Ton) & Toplam Rezerve Oranı (\%) \\
\hline Hindistan & 846.000 & 16 \\
\hline Türkiye & 744.000 & 14 \\
\hline Brezilya & 606.000 & 11 \\
\hline Avusturalya & 521.000 & 10 \\
\hline ABD & 434.000 & 8 \\
\hline Misır & 380.000 & 7 \\
\hline Norveç & 320.000 & 6 \\
\hline Venezuela & 300.000 & 6 \\
\hline Diğer Ülkeler & 1.234 .000 & 22 \\
\hline Dünya Toplam & 5.385 .000 & 100 \\
\hline
\end{tabular}

Kaynak: Kaya ve Kursunoglu, 2014.

Dünyanın en büyük ikinci toryum rezervlerine sahip Türkiye'nin toryum yatağı EskişehirBeylikhisar bölgesinde yer almaktadır. Türkiye sahip olduğu 380 bin ton rezerv ile 1 milyon 306 bin tonluk rezerve sahip Brezilya'dan sonra dünyada ikinci sırada yer almaktadır (Külebi, 2007: 179).

Toryum ihtiva eden Eskişehir-Sivrihisar cevher yatağındaki, Yaylabaşı ve Kocayayla sektörlerinde yeterli sayıda sondaj yapılamadığından bu bölgelere ait kesin rezerv tespiti mevcut değildir. Bu bölgelerle birlikte Malatya-Hekimhan-Kuluncak gibi diğer bölgelerde de gerekli çalışmaların yapılması sonucunda Türkiye toryum rezervinin artacağı tahmin edilmektedir. Ancak bu konu ile ilgili kesin sonuca götürecek herhangi bir çalışma yapılmamıştır (TAEK).

Dünya toryum rezervlerinin yüzde 70'e varan bir miktarı Türkiye'de olmasına, 250'den çok malzemede kullanılmasına, nükleer sanayiden, son y1llarda doğrudan ya da dolaylı olarak yakıt elde etme işinde de kullanılabileceği tartışılmasına karşın, ham madde olarak satılmasının kaynağın ekonomik değerini düşürdüğü söylenebilir. 1,2 milyar dolarlık bir sektör olan borun dünya gereksiniminin yüzde 95'ini Türkiye'nin karşılamasına karşın, toplam pazardaki payı yüzde 22'yi geçmemektedir (Erdoğan, 1998: 230).

\section{Türkiye’nin Enerji Politikalarının Nükleer Enerji Tercihindeki Etkisi}

Enerji konusunda bugüne kadar pek çok öngürü modeli oluşturulmuştur. Örneğin; geleceğe yönelik tahminlerini farklı senaryolar 1şığında, dünya enerji politikalarını kolaylaştırmayı hedefleyen Dünya Enerji Konseyi (WEC)'nin yayınladığı son rapora göre 2050 yılında fosil yakıtlarının ihtiyacın hala büyük kısmını karşılayacağını öngörmektedir. Bunun yanı sıra WEC'in müzik dallarından esinlenerek "Senfoni" ve "Jazz" benzetmelerini kullanarak oluşturduğu, iki farklı senaryo'da enerji arzının, talebi karşılayabilmesi için dünyanın enerji stratejileri açısından değerlendirmeleri yapılmıştır. WEC'in 40 yıl sonrasını dikkate alarak oluşturduğu Jazz senaryosunda, gelecekte enerji piyasasına tüketici isteklerinin yön vereceği varsayılırken, Senfoni senaryosunda ise çevre ile ilgili kaygıların öne plana çıkacağı bu yüzden enerji politikalarını hassas seçmenlerin şekillendirileceği öngörülmüştür (WEC, 2013:9). Türkiye'nin bu iki senaryonun da dışında kararlar aldığı son derece açıktır. 
Kişi başına yıllık yakıt ihtiyacının 1 ton olduğu varsayıldığında (bu rakam gelişmiş sanayi ülkelerinde, bir kişinin yıllık yakıt tüketimi 4 ton olarak değişmektedir), yeryüzündeki nüfusun yüzde 2 oranında arttığı düşünülürse, 2200 yılında yeryüzünde mevcut bütün doğal kaynakların tükeneceği tahmin edilmektedir. Nüfus yüzde 3 oranında arttığı takdirde, mevcut yakıtla ancak 2090 yılına kadar yeteceği düşünülmektedir. Doğal kaynakların hidroelektrik usullerle arttırılması her ne kadar mümkün oluyorsa da, 1 milyon tonu bulması imkânsızdır. Bunun için, eninde sonunda ya nükleer enerji, ya da henüz bilinmeyen, alternatif bir enerji kaynağ1 şarttır (Brown, 1964: 116).

İlk kez kullanımı yok etme amaçlı olmasına rağmen nükleer enerji; başlıca yakıt olarak kullanılan uranyumun çekirdeklerinin, nötronlarla bombardıman edilmesiyle ortaya çıkan reaksiyonların elektriğe dönüştüren bir ikincil enerji kaynağı olarak kullanılmaktadır. İkinci Dünya Savaşı sırasında ABD'nin atom bombası yapmak amacıyla kullandığı birçok tartışmaya da konu olan nükleer enerji, alternatif enerji kaynakları içinde ilk sırada yer almaktadır. Geçmişte nükleer enerjinin ticari anlamda elektrik enerjisini üretmek amacıyla kullanımı da yine ABD tarafindan ilk kez 1955 yılında olmuştur (White, 1998: 27). 1960'lı yıllar nükleer enerjinin teknik olarak güvenilir ve ekonomik olarak kullanılabilir bir enerji kaynağına dönüştüğü ve elektrik üreticilerinin normal olarak sipariş vermeye başladıkları y1llar olmuştur (Özemre vd., 2000:12).

Nükleer enerjinin üretilmesinde uranyum daha yoğun biçimde kullanılmakla birlikte son dönemde nükleer enerji üretiminde yakıt olarak toryum kullanan ve uranyumdan daha az tehlikeli olan toryumla çalışan nükleer santral teknolojisini geliştirmek üzere teorik ve uygulamalı faaliyetler Kanada, Hindistan ve Japonya gibi ülkeler tarafından yapılmaktadır (IAEA, 2013).

Petrol krizinin ortaya çıktığı 1970'li yılların başında, petrol fiyatlarının beklenmedik bir şekilde aşırı yükselerek iki katına çıkması elektrik üretimini arttırabilmek amacıyla nükleer santrallerin kurulmasını hızlandırmış ve nükleer santral sayısında büyük artış meydana gelmiştir. Three Mile Island (1979, ABD) ve Çernobil (1986, Sovyetler Birliği) nükleer kazalarının da etkisi bir tarafa, dünya ekonomisinde oluşan yavaşlama ve doğalgazın enerji piyasasına girmesi 1980 'lerin sonuna doğru nükleer enerjiye olan talep artı̧̧ı azalmaya başlamıştır. Nükleer santrallerin kurulmasında 90'lı yıllardan itibaren azalarak artış olmuştur.

Uluslararas1 Atom Enerjisi Ajansı (IAEA) 1974'te, 2000 yılına kadar dünyada 4.500 adet nükleer santral kurulup işletileceğini tahmin etmişti (IAEA, http://www.iaea.org/, 10.10.2013). Ancak günümüzde nükleer enerji üretimine bakıldığında durum bu şekilde gelişmemiştir. 2013 yılında dünyanın elektrik gereksinmesinin yüzde 13,5'ini karşılayan nükleer enerji, 2016 yılına gelindiğinde Dünya toplam enerji tüketiminin yüzde 10,6'sını karşılamaktadır. Son üç yılda nükleer enerjiden vazgeçilmesinin en büyük nedenlerinden birisi de Japonya'da yaşanan Fukushima nükleer santralinde yaşanan nükleer sızıntı felaketidir. Ayrıca tablo 6 da görüleceği üzere Almanya ve İngiltere gibi AB ülkelerinin artık nükleer enerjiden uzaklaşması nükleer enerji santrallerinin enerji tüketimi içindeki payının azalmasındaki en önemli neden olmuştur. 
Tablo 6: Dünya'da Nükleer Enerji Santrallerinde İlk 10 Ülke ve Türkiye

\begin{tabular}{|c|c|c|c|c|}
\hline ÜLKE & \begin{tabular}{|c|}
2013 Yılında \\
Faaliyetteki Nükleer \\
Enerji Santrali \\
Adedi \\
\end{tabular} & $\begin{array}{c}2014 \text { Yılında Faaliyete } \\
\text { Geçmesi Planlanan } \\
\text { Nükleer Enerji Santrali } \\
\text { Adedi } \\
\end{array}$ & \begin{tabular}{|c|}
2016 Yılında \\
Faaliyetteki Nükleer \\
Enerji Santrali \\
Adedi \\
\end{tabular} & $\begin{array}{c}2018 \text { Yılında Faaliyete } \\
\text { Geçmesi Planlanan } \\
\text { Nükleer Enerji Santrali } \\
\text { Adedi } \\
\end{array}$ \\
\hline $\mathrm{ABD}$ & 100 & 9 & 99 & 14 \\
\hline Fransa & 58 & 1 & 58 & 0 \\
\hline Japonya & 50 & 9 & 42 & 9 \\
\hline Çin & 17 & 59 & 38 & 39 \\
\hline Rusya & 33 & 28 & 35 & 26 \\
\hline $\begin{array}{l}\text { Güney } \\
\text { Kore }\end{array}$ & 23 & 6 & 24 & 1 \\
\hline Hindistan & 20 & 18 & 22 & 19 \\
\hline Kanada & 19 & 2 & 19 & 2 \\
\hline Ukrayna & 0 & 2 & 15 & 2 \\
\hline İngiltere & 16 & 4 & 15 & 11 \\
\hline Almanya & 9 & 0 & 7 & 0 \\
\hline Türkiye & 0 & 4 & 0 & 4 \\
\hline Dünya & 426 & 173 & 447 & 157 \\
\hline
\end{tabular}

Kaynak: http://www.world-nuclear.org/information-library/facts-and-figures/world-nuclear-power-reactors-anduranium-requireme.aspx

Tablo 6'da yer almayan İsviçre, Belçika gibi diğer AB üyesi ülkeler de nükleer enerji programlarını aşamalı olarak azaltma hatta sonlandırma kararı almıştır. Bu ülkelerin yanı sıra nükleer programını değiştirmeyen ve planladıkları gibi nükleer enerji santralleri kurma çalışmalarına devam eden birçok ülke (örneğin; AB ülkelerinden Polonya, Slovakya ile Çin, Hindistan, ABD, Arap Emirlikleri, Vietnam, Türkiye) bulunmaktadır (Rovny, 2012: 19). Dünyanın petrol sonrası döneme geçişinin ardından nükleer enerji, "ucuz, temiz ve emin" yoldan sağlanacak en büyük enerji kaynağı olarak kabul ediliyordu. 20. yüzyıl sonuna doğru bunun o kadar kolay olmayacağ 1 anlaşılmasına rağmen, gelişmiş veya gelişen pek çok ülkede, nükleer santrallerin gittikçe yayılmakta olduğu bir gerçektir. Bu ülkeler arasında elektrik enerji talebinin bir kısmını nükleer kaynaklardan sağlamayı planlayan Türkiye de yer almaktadir.

Ülkelerin nükleer enerjiyi tercih etmesine neden olan avantajları konusundaki farklı görüşleri şu şekilde sıralayabiliriz;

- Nükleer enerji santralleri, termik santralle karşılaştırılacak olursa atmosfere karbondioksit salmaz, çevreyi kirletmez (Özemre vd., 2000: 12),

- Nükleer ve termik santraller ile yapılan elektrik üretiminin hem yatırım, hem de işletim maliyetleri açısından her güneş ve rüzgar enerjisi ile üretime göre daha 
elverişli elektrik enerjisi üretim sistemleridir. Nükleer enerji üretimi, diğer birçok enerji kaynağına oranla daha ekonomiktir (Kessides, 2010: 3851). Nükleer enerji üretiminde kullanılan yakıtlardaki atomun çekirdeğindeki enerji serbest bırakıldığında büyük bir enerji açığa çıkardığından nükleer enerjiden elde edilen elektriğin ucuz bir şekilde elde edilmesi söz konusu olmuştur (Bockris vd., 2002: 41).

- Bir nükleer enerji santralinde, 1 tonluk uranyum yakıtı, binlerce ton kömürün verdiği enerjiyi verecek kadar etkilidir; buna göre yeryüzünde mevcut uranyum, çok uzun yıllar enerji ihtiyacını karşılayacağı düşünülmektedir (Brown, 1964: 116).

- Nükleer enerji üreten ülke doğal uranyum ve toryum yataklarını nükleer yakıt olarak kullanabiliyorsa kaynak bakımından dış ülkelere bağımlı olmaz, üretim birim fiyatı termik santrallerininkinden daha ucuza mal olan güçlü bir ekonomik olanak sağlar (Özemre vd., 2000: 12).

- Nükleer enerji üretiminin kalitesini; düşük üretim maliyeti, uzun işletme ömrü, yüksek ilk yatırım maliyeti, gerekli yasal düzenlemeleri ve uzun işletme ömrü ile ölçmek mümkündür (NEA, 1998). Nükleer santrallerin ortalama 30-40 y1ll1k işletme ömür vardır. 1960-1970 yıllarında inşa edilen nükleer santrallerin 20002010 yıllarında sökülmesi, ancak yerine yeni nükleer santrallerin yapılmas1 en az 10 y1l önceden planlanmalıdır (White, 1998).

- Yeni bir teknolojinin ülkeyi her yönden (teknolojik, kültürel, ekonomik vd.) zenginleştireceği düşünülmektedir, ülkenin nitelikli personel potansiyelini arttırır (Özemre vd., 2000: 10),

- Nükleer enerji santrallerinin kurulması, az gelişmiş bir bölgenin sanayileşmesinde büyük rol oynar (Brown, 1964: 118).

Ekonomik anlamda nükleer enerjinin hesaplı bir enerji kaynağı olması üzerine, bugüne kadar birçok çalışma yapılmıştır. Nükleer enerji konusunda ilerlemeye kaydeden ülkelerin bilimsel ve teknolojik alanda da gelişim sağladığı görülmektedir. Nükleer teknoloji transferini çok başarılı bir şekilde gerçekleştiren ülkelerin başında gelen Güney Kore'nin, bu gibi kazanımlar sayesinde, diğer teknolojik alanlarda elde ettiği başarılı sonuçlar bilinmektedir. Nükleer enerji santrallerinde kullanılan parçaların diğer teknoloji ürünlerinin geliştirilmesinde de fayda sağladığı Güney Kore örneği ile son dönemde sürekli ifade edilmektedir.

Farklı görüşler çerçevesinde nükleer enerjinin dezavantajlarını şu şekilde sıralayabiliriz:

- Nükleer enerjinin en önemli özelliği olan yakıtın (uranyum) hem kömüre, hem de petrole göre daha fazla depolanmış enerji içermesi sebebiyle diğer enerji kaynaklarına göre daha az miktarda yakıta ihtiyaç duyulmasının yanı sıra nükleer enerjinin getirdiği en önemli problem, kansere yol açtı̆̆ bilinen ve dolayısıyla oldukça tehlikeli olan radyasyondur (Bockris vd., 2002: 96). 
- Uranyumun diğer madenler gibi kolayca alınıp satılamaması, nakliyesinin çok sıkı kurallara, ülkeler arasındaki bazı anlaşmalara ve uluslararası denetime bağlı olması nedeniyle, nükleer santral kuran veya kurmayı planlayan ülkeler, kendi uranyum kaynaklarını bularak değerlendirmeyi amaçlamaktadırlar Kessides, 2010: 3851). Ancak her ülkede doğal bir yeraltı rezervi olarak uranyum olmayabilir. Bu da yüne dışa bağımlılık demektir.

- Önceleri tükenmez bir elektrik kaynağ 1 olarak düşünülen nükleer enerji, başlangıçta düşünüldüğü kadar inanılmaz ölçüde ucuz olmasına karşın nükleer santrallerin inşa, çalışma ve bakımındaki pahalılıktan dolayı, yüksek maliyet arz etmeye başlamıştır (Altın, 2006: 34 -49).

- Nükleer santralin bir diğer dezavantajı radyoaktif izotopların, reaktör kalbini soğutan suya karışmasıdır. Suyun içerisinde dolaşan nötronlar, suyu oluşturan çekirdekler tarafindan yutulmaktadırlar. Bu durumda hidrojen, bir nötron yutup döteryum, döteryum da bir nötron daha yutup trityum olabilir. Her iki ürün de radyoaktiftir. Benzer şekilde, sudaki oksijen bir nötron yutup radyoaktif bir izotopa dönüşebilir. Dolayısıyla, soğutma suyu, reaktör içerisinde dönüp durdukça radyasyon biriktirir ve dışarı sızmaması gerekmektedir (Altın, 2006: 49).

Nükleer enerji santrallerinde geçmişte meydana gelen kazalar ve son dönemde Japonya depremi ardından Fukushima nükleer santralinde yaşanan büyük tehlikenin ardından, nükleer enerji üretiminde yönetim, güvenlik ve ticarete yapılan her ek harcama nükleer enerjiyi pahalı hale getirmiştir. Özellikle 1980'li yıllarda yüksek maliyetler sebebiyle bir çok yeni reaktörün kurulumu aşamasında sıkıntılar yaşanmış bir çoğunun kurulumu durdurulmuştur. Örneğin, 1978 yılından 1995 yılına kadar Amerika'da nükleer santral kuruluşuna ara verilmiştir. 1980 yılında nükleer güç santrallerinin verimi yüzde 60 civarındayken, 2001 yılı sonu itibariyle bu değer yüzde 30 artış ile yüzde 90 'a çıkmış durumdadır. Bu artış yakın zamanda toryum gibi yeni elementlerin yakıt olarak kullanılmasıyla daha da artmas1 beklenmektedir. Enerji açığının kapatılmasında nükleer enerjinin önemi, bir kez daha ortaya çıkmaktadır. Toryum uranyum gibi doğrudan enerji üretilebilecek bir madde olmamasına karşın, uranyum ve/veya plütonyumla birlikte kullanıldığında, uranyuma göre fazla ve uzun sureli enerji üretme kapasitesine sahiptir. Toryum katkılı yakıtlar, sırf uranyum içeren yakıtlara göre çok daha az miktarda bölünme ürünü (radyoaktif atıklar) çıkartmaktadırlar. Bütün bu avantajlar toryumu nükleer yakıt olarak kullanmak için cazip hale getirmektedir (White, 1998: 28).

Türkiye enerji ihracatının büyük bir kısmını enerji dağıtımında köprü vazifesi görmesi sebebiyle boru hatlarından dağıtılan petrol ve doğal gaz oluşturmaktadır. Ancak cari açık çıkmazı ve sürekli artan enerji talebi Türkiye'nin enerji politikalarını, yenilenebilir enerji kaynakları potansiyeli ve diğer alternatifleri de dikkate alarak şekillendirmesini gerektirmektedir. Son dönemde enerji politikaları açısından sürekli gündemde olan Türkiye'nin nükleer enerji ile elektrik enerjisi üretimini sağlayacak şekilde bir enerji politikasını izlemeye yönelmiş olduğu görülmektedir. Bu açıdan Türkiye'nin enerji politikası aracı olarak ilk sıraya koyduğu nükleer enerji alternatifinin seçimine yönelmesi önemli bir gelişmedir. 
Türkiye nükleer enerji ile ilk kez 1950'li yılların ortalarında tanışmış ve bugüne kadar nükleer enerjinin çevreye vereceği zararlar etrafında tartışmalar devam ederken bilimsel bir altyapıda nükleer enerji konusu halkın gündeminde tartışılmamıştır.

Türkiye, ABD ile 5 Mayıs 1955 yılında ikili işbirliği anlaşması imzalamış ve Türkiye imzaladığı bu ikili anlaşmayla 1956'da AEK(Atom Enerjisi Kurumu) Kanunu'nu çıkartarak Atom Enerjisi Komisyonu Genel Sekreterliğini 1956 yılında 6821 sayılı yasa ile Başbakanlık'a bağlı olarak Ankara'da kurdu böylece nükleer enerjide ilk teknik adımı atmış oldu (TAEK). Ardından Türkiye 1957 yılında Birleşmiş Milletlerin önemli bir kuruluşu olan Uluslararası Atom Enerjisi Ajansı (IAEA)'nın üyesi olmuştur (Thinktech, 2017).

$\mathrm{Bu}$ yapısal çalışmaların yanında Türkiye'de nükleer enerji üretimine ilişkin ilk fiziki çalışmalar, 1960'lı yıllarda İstanbul Nükleer Enerji Enstitüsü ve Türkiye Atom Enerjisi Kurumu (TAEK)'na bağlı olarak çalışan Çekmece Nükleer Araştırma ve Eğitim Merkezi'nde olmak üzere kullanılan küçük çaplı iki nükleer araştırma reaktörüne dayanmaktadır (TÜYAP, 1998: 28). 1970'li yılların sonlarında nükleer santral yapımı konusu gündeme gelmiş, fakat Mersin-Akkuyu beldesinde ön çalışmalar yapılmasına rağmen bu santralin kurulum aşamasına bu dönemde geçilememiştir (Karluk, 2014, 246).

2020 yılında üretilen elektriğin yüzde 9'nun nükleer enerjiden sağlanmasının hedeflendiği Mersin Akkuyu'daki bu santralin 2005 yılında ihalesinin sonuçlandırılarak inşaata başlanması ve 2010 yılında ilk nükleer santralin devreye alınması gerekirken, Mersin'de kurulacak nükleer santral 2010 yılında Rusya ile, Sinop'ta planlanan nükleer santral ise 2013 yılında Japonya ile yapılan anlaşma kapsamında resmiyet kazanmıştır ve bu iki santral sırasıyla 2022 yılı ile 2028 yilında tamamen faaliyete başlayacaktır (ETKB, 2017). 2017 yılında yapılan açıklamalara bakıldığında üçüncü nükleer santral için de çalışmaların başladığı görülmektedir. Türkiye açısından değerlendirildiğinde Güney Kore'deki nükleer endüstrinin gelişimi bizim için iyi bir örnek oluşturmaktadır. Güney Kore ilk nükleer santralinde yalnızca yüzde 2 oranında bir yerel katkı sağlayabilmekteyken, günümüzde, yüzde 98'i milli kaynaklarla inşa edilen nükleer santral projeleri tasarlayabilmektedir. Dünyada nükleer santral teknolojisinin geliştirilmesi 1940 'l y yllardan itibaren, başta ABD olmak üzere Rusya, Fransa, İngiltere ve Kanada tarafından başlatılmıştır. Diğer tüm ülkeler, nükleer santral teknolojisini bu ülkelerden ithal etmişlerdir. Almanya, Japonya, Hindistan ve Güney Kore gibi ülkeler ithal ettikleri teknolojiyi daha da geliştirerek kendilerine has nükleer santral tasarımlarına sahip olmuşlardır (ETKB, 2011: 47).

\section{Sonuç}

Enerji, uluslararası politikalara yön verebilen güçlü bir enstrümandır. Kısa ve uzun vadede güvenilir kaynaklarından enerji ihtiyacını sağlama anlayışı, küreselleşme ile birlikte enerji dünyasının en kritik konusu haline gelmiştir. Dünyada özellikle gelişmekte olan ülkelerde hızlı nüfus artışı ve endüstrileşme, elektrik enerjisine olan talebi de hızla artırmaktadır. Günümüzde ekonomik yeterlilik, bir ülke için bağımsızlığın temel ilkelerinden biridir. Ekonomik yeterliliğin sağlanması, o ülkenin ihtiyacını karşılayacak enerjiye sahip olmasına bağlıdır.

Türkiye gibi pek çok gelişmekte olan ülkenin enerji talebi ve enerjide dişa bağımlılığı her geçen gün artmaktadır. Cari açığımızın bu kadar yüksek olmasının yanında bu açığın büyük bir kısmının enerji ithalatından kaynaklanması nedeniyle küresel ölçekte yaşanan her 
dalgalanma kur ve petrol fiyatlarına da yansıdığından cari açı̆̆ımızda anında olumsuz yönde etkilenmeye devam etmektedir. $\mathrm{Bu}$ da Türkiye ekonomisini her türlü dalgalanmada savunmasiz birakan bir durumdur.

Türkiye'nin enerji ihtiyacının yarısından fazlasını ithal eden bir ülke olması bakımından enerjide dışa bağımlılı̆̆ gelmektedir. Diplomasi alanında yaşanan en küçük sorunun Türkiye'nin enerji sektörüne yansımalarını gündelik yaşam içerisinde gördüğümüz geçmiş deneyimlerden yola çıkarak enerji konusunun Türkiye için ne denli önemli olduğunu görmemiz mümkündür.

Ekonomik gelişimi ile birlikte sanayide ve günlük ihtiyaçlarda Türkiye'nin elektriğe olan talebin her geçen gün artmasıyla alternatif enerji kaynaklarına olan ihtiyaç da artık göz ardı edilebilecek bir durum değildir.

Türkiye'nin enerji politikasını belirleme aşamasında ilk sırada değerlendirdiği, elektrik üretiminde temiz enerji olarak en bilinen hidroelektrik santraller için suya ve büyük su alanlarına ihtiyaç duyulmaktadır. Normal şartların hüküm sürdüğü bir yıl boyunca, elektrik üretimi için yeterli su bulunabilir; kuraklık dönemlerinde ise, normal elektrik üretimi önemli ölçüde etkilenmektedir. Ayrıca, havalar daha sıcak olduğunda elektriğe olan talep artmakta (klima gibi soğutucu cihazların kullanımı artar), fakat ısının yol açtığı su açıklarından dolayı da elektrik üretim kapasitesi oldukça düşmektedir (Bockris vd., 2002: 61).

Hükümetin desteği, yenilenebilir enerji teknolojisini geliştirmek için yeterli değildir. Genç ve bilinçli nüfusu, yenilenebilir enerji potansiyeli, gibi pek çok kaynağı ile Türkiye, enerji ihtiyacını sadece nükleer enerjiye dayandırarak büyük bir hataya düşmek yerine elindeki tüm kaynakları verimli bir şekilde kullanarak enerji-cari açık çıkmazını rahat bir şekilde aşabilir. Enerji Bakanlığ kapsamında oluşturulabilecek bir birimin bilimsel araştırma merkezlerinin de arttırılmasını sağlayarak enerji teknolojisini destekleyen çalışmalara hız vermesi gerekmektedir. Sosyal sorumluluk projeleri ve kitlesel iletişim araçları ile yenilenebilir enerji ya da başka alternatifler konusunda tüm Türk halkını teşvik edecek adımlar atılması şarttır. Ayrıca, Türkiye'nin en büyük ve sağlam yapısı olan bankacılık ve finans sektörünü de devreye sokarak enerji konusunda özel bankaların Türkiye'deki ticari uygulamalardaki desteğini arttırması gerekmektedir.

Alternatif enerji kaynağı olarak diğer bir seçenek olan nükleer enerji santrallerinden kaynaklanan risk ihtimali milyonda bir de olsa nükleer santraller tehlikelidir ve tehlike yerel değil, aksine küresel ölçüde tehdit unsurudur. Öte yandan Türkiye'de nükleer santrallerin kurulumu tehlikedir şeklinde bir sav geliştirmek de hatalı olacaktır. Nitekim, Ermenistan'ın elektrik enerjisi ihtiyacının yaklaşık yüzde 27'ini karşılamakta olan nükleer enerji santrali doğu sınırımıza sadece $10 \mathrm{~km}$ mesafe uzaklıkta faaliyet göstermekte ayrıca diğer bir gerçekte Ermenistan'ın bu nükleer santralinde çok eski teknoloji kullanılmaktadır. Kısaca bu santralde meydana gelecek bir risk Çernobil faciasında olduğu gibi Türkiye'yi de etkileyecektir.

Nükleer enerji üretimine yönelik tesisler güvenlik ve kalite kültürünün Türkiye'de yerleşmesinde ve gelişmesinde önemli bir yeri olacağ 1 beklenmektedir. Nükleer enerji üretimi için kurulacak tesisler, Türkiye'de, nükleer teknoloji alt yapısının gelişmesine katkı sağlayacaktır. Ayrıca, nükleer santrallerden üretilecek enerji ülke enerji üretim portföyüne çeşitlilik getirebilecek bir seçenektir. Nükleer santraller günümüzde yüksek yük faktörü ile 
çalışabilen ve lisanslama kuruluşları tarafindan sürekli denetime tabi tutulan tesisler olarak dünya enerji üretiminde önemli bir paya sahiptir (Glaser, 2011:29).

Nükleer enerjinin üretimi esnasında kullanılan uranyum hammaddesinin daha az riskli bir alternatifi olduğu son dönemde tartışılmaya başlamıştır. Başta Kanada ve Güney Kore olmak üzere nükleer enerji santrali kurulumunu yapan ülkeler toryum ile elektrik enerjisi üretimi için teknolojilerini geliştirmeye çalışmaktadırlar. Toryum gibi yerli kaynağımızın varlığı, gelecekte tam olarak nükleer enerji kullanımında Türkiye için bir güvence olduğu son derece açıktır. Dünya genelinde yapılan çalı̧̧maların getirdiği bir sonuç olarak; Türkiye, toryumun yeni nesil nükleer santrallerde kullanılmaya başlaması ile birlikte daha güvenilir ve temiz bir yerli kaynakları elektrik enerjisi ürettiği bir alternatif enerji kaynağına sahip olabilmesi mümkündür.

Tüm bu açıklamalar doğrultusunda enerji açığının kapatılmasında diğer avantajları ile nükleer enerjinin önemi, bir kez daha ortaya çıkmaktadır. Toryum uranyum gibi doğrudan enerji üretilebilecek bir madde olmamasına karşın, uranyum veya plütonyumla birlikte kullanıldığında, uranyuma göre fazla ve uzun sureli enerji üretme kapasitesine sahiptir. Toryum katkılı yakıtlar, sırf uranyum içeren yakıtlara göre çok daha az miktarda bölünme ürünü (radyoaktif atıklar) çıkartmaktadırlar. Toryum sadece elektrik enerjisi ihtiyacını gidermek amacıyla nükleer enerji santralinde kullanıldığı gibi endüstride kullanılan birçok izotopun üretilmesi yolu ile diğer sektörler için de önem arz etmektedir. Dünyanın ikinci büyük toryum rezervlerine sahip olan Türkiye'nin, bu yeraltı zenginliğini çok iyi bir şekilde kullanarak değerlendirmesi Türkiye ekonomisi açısından katma değeri yüksek bir tercih olacaktır. 


\section{KAYNAKÇA}

ALTIN, V. (2006). "Nükleer Dosya", Bilim ve Teknik Dergisi, S. 460, İstanbul.

ARI, T. (2007). Irak, İran, ABD ve Petrol, Alfa Yayınları, Güncellenmiş 2. bs., İstanbul, Ocak

BAŞOL, K. (1994). Doğal Kaynaklar Ekonomisi, Anadolu Matbaası, İzmir.

BROWN, B (1964). "The Economics of Nuclear Power", Maden Tektik ve Arama Dergisi, S. 62, İstanbul.

BOCKRIS, J. O’M. VEZİROĞLU, T. N. SMITH D. L. (2002). Geleceğin Enerjisi: Güneş Hidrojen, Kaynak Yayınları, İstanbul.

DAVIS, S. VE HALTIWANGER, J. (2001). Sectoral Job Creation and Destructionesponse to Oil Price Changes. Journal of Monetary Economics, 48,465-512.

DEMIR, M. (2013). Enerji İthalatı Cari Açık İlişkisi, Var Analizi İle Türkiye Üzerine Bir İnceleme, Akademik Araştırmalar ve Çalışmalar Dergisi, Y11 5 - Sayı 9, ss. 2-27.

DÜNDAR C., ARIKAN Y. (2003). "Enerji, Çevre ve Sürdürebilirlik”, TMMOB Türkiye VI. Enerji Sempozyumu Bildiriler Kitabı, Ankara.

ETKB, (2016). Türkiye'nin Nükleer Santral Projeleri: Soru-Cevap, Nükleer Enerji Proje Uygulama Dairesi Yayın Serisi, 11 Ocak 2016 http://www.enerji.gov.tr/File/?path=ROOT\%2f1\%2fDocuments\%2fSayfalar\%2fT\% C3\%BCrkiyenin_N\%C3\%BCkleer_Santral_Projeleri_Soru-Cevap.pdf (01.02.2018)

ETKB, (2017). http://www.enerji.gov.tr/yayinlar_raporlar/Nukleer_Santraller_ve_Ulkemizde_Kurul acak_Nukleer_Santrale_Iliskin_Bilgiler.pdf, (20.09.2017).

ETKB, (2017a). http://www.enerji.gov.tr/yayinlar_raporlar/Dunyada_ve_Turkiyede_Enerji_Gorunum .pdf, (16.11.2017).

GLASER, A. (2011). "After Fukushima: Preparing for a More Uncertain Future of Nuclear Power", July, Vol. 24, Issue 6.

GÜNEY, Y. (2003). AB Enerji Politikası ve Türkiye'ye Yansımaları: AB'de Enerji ve Rekabet, AB'de Elektrik Piyasaları, UPAV Yayınları, Ankara.

GÜREL, M. (1980). "Enerji-Petrol ve Türkiye", P.İ.G.M. Dergisi, S. 25, Ankara.

HAMILTON, J., (1988). A Neoclassical Model Of Unemployment and Thebusiness Cycle. The Journal of Political Economy, 96 (3), 593-617.

HAMILTON, J. (1996). This Is What Happened To The Oil PriceMacroeconomyrelationship? Journal of Monetary Economics 38, 215-220.

HAMILTON, J. (2000). What Is An Oil Shock? Journal of Econometrics, 113,363-398.

IAEA. http://www.iaea.org/, (09.01.2018).

IAEA, (2013). "Key World Energy Statics 2013”, http://www.iea.org/publications/freepublications/publication/KeyWorld2013_FINA L_WEB, (17.09.2017).

IRENA, (2014). "REmap 2030: A renewable Energy Roadmap", http://irena.org/remap/REmap\%20Summary\%20of\%20findings_final_links.pdf, (17.09.2017).

KAYA, M., KURSUNOGLU S. (2014). Thorium Fuel For Nuclear Energy, XXVII IMPC.

KARAGÖL, E. T. KAVAS, İ. (2017). Dünyada ve Türkiye'de Yenilenebilir Enerji, SETA Siyaset, Ekonomi ve Toplum Araştırmaları Vakfi Yayınları, S. 197.

KARLUK, R. (2014). Cumhuriyetin İlanından Günümüze Türkiye Ekonomisi’nde Yapısal Dönüşüm, Beta Yayınları, Gözden Geçirilmiş 13. bs., İstanbul. 
KESSIDES, Ioannis N. (2010). "Nuclear power: Understanding the Economic Risks and Uncertainties", Energy Policy, Cilt.38, s.3849-3864.

MELIKOĞLU, M. (2013). Vision 2023: Forecasting Turkey's Natural Gas Demand Between 2013 and 2030. Renewable and Sustainable Energy Reviews, Volume 22, June 2013, Pages 393-400

NEA (1998) "Reduction of Capital Costs of Nuclear Power Plants", Paris:OECD, 1998. http://www.nea.fr/, (16.11.2017).

NEA, (2006) "Nükleer Enerji Yoğunluğu", http://www.iea.org/textbase/nppdf/free/2006/weo2006.pdf, (18.01.2018).

ÖZEMRE, A. Y., BAYÜLKEN A., GENÇAY, S. (2000).50 Soruda Türkiye'nin Nükleer Enerji Sorunu, İstanbul: Kaknüs Yayınları.

ROVNY, J. (2012). "Nuclear Energy After Fukushima? Strong And İndependent National Regulators", International Issues \& Slovak Foreign PolicyAffairs, Vol. XXI, No. 1S, 2012, pp. $11-20$.

SATMAN, A. (2006). Dünyada Enerji Kaynakları, Tasam Yayınları, Türkiye'de Enerji ve Kalkınma Sempozyumu: İstanbul, Nisan 2006.

SAYSEL, A. K. (2008). "Nükleer Santrallerin Bir Ekonomisi Var mı?”, http://www.bilimart.com/biyoloji/2008/02/nukleer-santrallerin-bir-ekonomisi-var$\mathrm{mi} /,(17.09 .2017)$.

TAEK: "Türkiye'nin Toryum Rezervi”, http://www.taek.gov.tr/bilgi/yakit/toryum/toryum_bilgi.html, (19.09.2017).

TECER, M. (2003). Türkiye Ekonomisi, Türkiye ve Orta Doğu Amme İdaresi Enstitüsü Yayınlart, 1. bs., Ankara.

THINK TECH. (2017). Nükleer Enerji ve Türkiye. https://thinktech.stm.com.tr/uploads/raporlar/pdf/13720171796510_satm_bb_17_020 0_nukleer_enerji_220617_.pdf (16.01.2018).

TÜYAP (1998). Türkiye'de Enerji Sektörü, Evgin Menkul Değerler Araştırma Yayınları: 1, İstanbul.

UYSAL, D. YILMAZ, K. Ç. TAŞ, T. (2015). Enerji İthalatı ve Cari Açık İliş̧isi: Türkiye Örneği, Muş Alparslan Üniversitesi Sosyal Bilimler Dergisi, Cilt:3 Sayı:1, ss. 63-78.

WEC, (2013), WEC World Energy Scenarios: Composing Energy Futures to 2050 https://www.worldenergy.org/wp-content/uploads/2013/09/World-EnergySenarios_Composing-energy-futures-to-2050_Full-report.pdf, (26.01.2018).

WHITE, J. E.(1998). "Implementation and Effect of High-Performance Work Practices in Nuclear Power Plants", The Pennsylvania State University, August. 